\title{
Intraductal Carcinoma of the Prostate
}

\section{Prostatın Intraduktal Karsinomu}

\author{
Kutsal Yörükoğlu \\ Dokuz Eylül University Faculty of Medicine, Department of Pathology, İmir, Turkey
}

\section{Introduction}

Intraductal carcinoma of the prostate (IDC-P) is characterized by malignant cells expanding the lumen of prostatic ducts and acini (Figure 1) (1). The basal cells are completely or partially preserved (Figure 2). The malignant cells filling the gland cause trabecular, cribriform, micropapillary or solid pattern $(2,3,4,5)$. The glands with intraductal carcinoma are more than twice the diameter of normal peripheral zone glands and may show branching typically at the right angles (Figure 3). The contour of the glands is smooth in contrast to benign and high-grade prostatic intraepithelial neoplasia (H-PIN). There may be comedonecrosis (2). The cells show generally two different populations. The outer layer cells are pleomorphic with marked nuclear atypia and six times larger than benign nuclei. They are mitotically active and stain poorly for prostate specific antigen (PSA) immunohistochemically (1). The inner group cells are small (Figure 3). They are monomorphic cuboidal cells with abundant cytoplasm and strong PSA staining. There may be extracellular mucin (Table 1).

The differential diagnosis of IDC-P includes cribriform H-PIN, invasive cribriform adenocarcinoma, ductal adenocarcinoma, and intraductal spread of urothelial carcinoma. H-PIN lacks solid and cribriform patterns, comedonecrosis, two different cell populations,

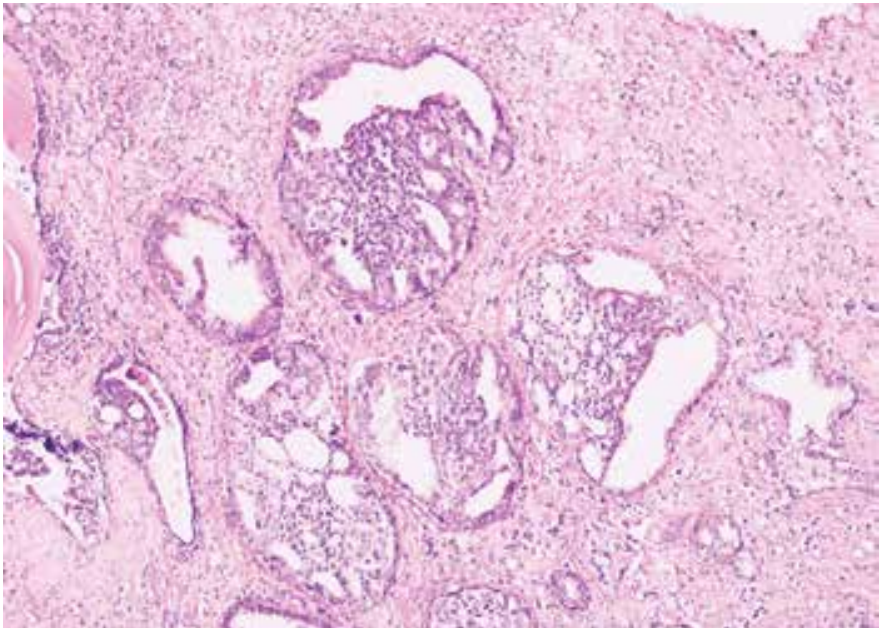

Figure 3. Intraductal carcinoma of the prostate with a right angle branching and two different cell population and marked nuclear enlargement. Ductal adenocarcinoma has papillary structures with fibrovascular cores, and basal cells are usually absent. Cribriform adenocarcinoma shows irregular and invasive borders and absence of basal cells. Urothelial carcinoma

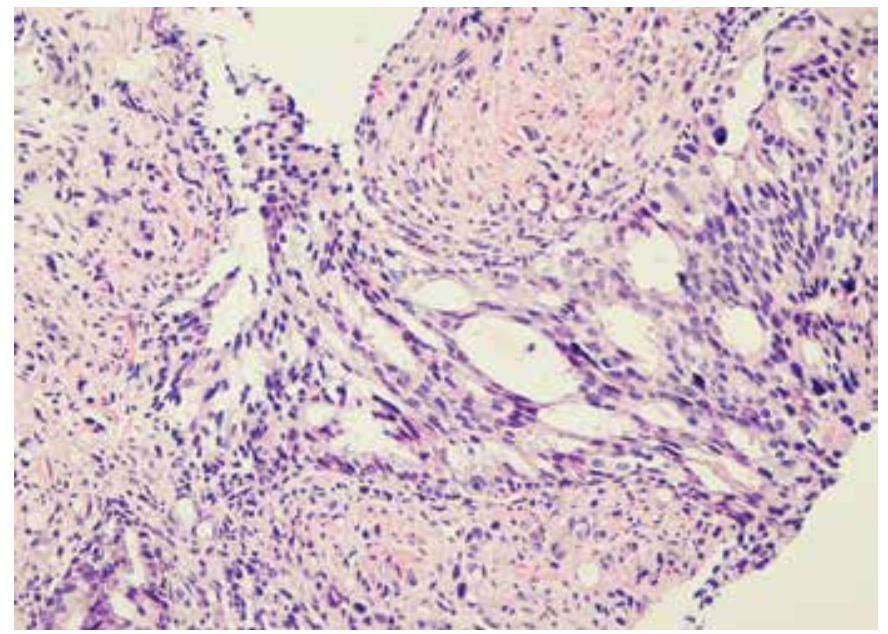

Figure 1. Intraductal carcinoma of the prostate shows the architecture of prostatic duct with a loose cribriform pattern



Figure 2. Intraductal carcinoma of the prostate in Figure 1 with basal cells around the duct immunohistochemically highlighted with high molecular weight cytokeratin

\section{Correspondence}

Kutsal Yörükoğlu MD, Dokuz Eylül University Faculty of Medicine, Department of Pathology, İmir, Turkey E-mail: kutsal.yorukoglu@deu.edu.tr Received: 09.03.2015 Accepted: 09.04.2015 


\section{Table 1. Morphologic features of intraductal carcinoma}

\section{Major}

Large glands ( $x 2$ of peripheral zon glands $=300 \mu \mathrm{m}$ )

Preservation of basal cells

Malignant cells

Cells spanning the lumen

Non-focal comedonecrosis $( \pm)$

Minor

Glands branching at right angles

Smooth gland contour

Two population of cells:

Tall columnar, pleomorphic, mitotically active peripheral cells Cuboidal, monomorphic, quiescent central cells

\begin{tabular}{|l|}
\hline Patterns \\
\hline Trabecular \\
\hline Micropapillary \\
\hline Cribriform (Compact or loose) \\
\hline Solid \\
\hline Comedonecrosis \\
\hline
\end{tabular}

with intraductal spread generally does not show cribriform pattern and the immunohistochemical staining profile is different $(2,3)$.

Spatial association, microinvasion, and similar molecular alterations in H-PIN and invasive carcinoma suggest H-PIN to be a precursor for low-grade cancers. High-grade prostate cancers are suggested to develop from either low-grade tumors or from H-PIN. Molecular alterations in high-grade prostate cancers and IDC-P are similar and IDC-P is suggested to evolve by the spread of high-grade cancer cells to preexisting ducts or develop de-novo from H-PIN. Therefore, IDC-P is a distinct entity from H-PIN (1).

When intraductal carcinoma is diagnosed with a concomitant invasive carcinoma in a prostate biopsy, reporting may not make any sense. However, intraductal carcinoma is frequently associated with high-grade, high-volume prostate carcinoma and poor prognosis; represents the intraductal spread of high-grade cancer and points to advanced-stage disease (2) and recommended to be reported $(3,4)$. However, it is very critical to report when there is no concomitant invasive carcinoma. In these cases, IDC-P should be reported with a comment stating its association with high-grade and high-volume cancer with a recommendation of either a definitive therapy or immediate repeat biopsy $(3,4,5)$.

Key Words: Prostate, intraductal, carcinoma, carcinoma in situ

Anahtar Kelimeler: Prostat, intraduktal, karsinom, karsinoma in situ Concept: Kutsal Yörükoğlu

\section{Design: Kutsal Yörükoğlu}

\section{Data Collection or Processing: Kutsal Yörükoğlu}

Analysis or Interpretation: Kutsal Yörükoğlu

Literature Search: Kutsal Yörükoğlu

Writing: Kutsal Yörükoğlu

Peer-review: Internal peer-reviewed.

Conflict of Interest: No conflict of interest was declared by the authors.

Financial Disclosure: The authors declared that this study has received no financial support.

\section{References}

1. Cohen RJ, Wheeler TM, Bonkhoff $H_{1}$ Rubin MA. A proposal on the identification, histologic reporting, and implications of intraductal prostatic carcinoma. Arch Pathol Lab Med 2007;131:1103-1109.

2. Guo CC, Epstein JI. Intraductal carcinoma of the prostate on needle biopsy: histologic features and clinical significance. Mod Pathol 2006;19:15281535.

3. Robinson B, Magi-Galluzzi C, Zhou M. Intraductal carcinoma of the prostate. Arch Pathol Lab Med 2012;136:418-425.

4. Montironi R, Scarpelli M, Cheng L, Lopez-Beltran A, Zhou M, Montorsi F. Do not misinterpret intraductal carcinoma of the prostate as high-grade prostatic intraepithelial neoplasia! Eur Urol 2012;62:518-522.

5. Robinson BD, Epstein Jl. Intraductal carcinoma of the prostate without invasive carcinoma on needle biopsy: emphasis on radical prostatectomy findings. J Urol. 2010;184:1328-1333. 